\title{
EFFECT OF METAKAOLIN ON COMPRESSIVE STRENGTH OF CONCRETE CONTAINING GLASS POWDER
}

\author{
Duna Samson ${ }^{1}$, Musa Abdullahi ${ }^{2}$, Mohammed Abba-Gana ${ }^{3}$ \\ ${ }^{1}$ Associate Professor, Department of Civil Engineering, Abubakar Tafawa Balewa University, Bauchi, Nigeria \\ ${ }^{2}$ Graduate student, Department of Civil Engineering, Abubakar Tafawa Balewa University, Bauchi, Nigeria \\ ${ }^{3}$ Associate Professor, Department of Civil Engineering, Abubakar Tafawa Balewa University, Bauchi, Nigeria
}

\begin{abstract}
This paper presents the results of the investigation into the effect of metakaolin (MK) on the compressive strength of concrete containing glass powder (GP). Plain mix, binary mixes (containing $10 \% \mathrm{GP}$ only by weight of cement) and ternary concrete mixes (containing 10\% GP with 5, 10,15 and $20 \%$ MK by weight of cement) were produced and cured for 7, 14, 28, 56 and 90 days respectively. A total of ninety (90) cubes were cast and tested for compressive strength. The results showed that generally compressive strength decrease with increase in $M K$ content and increase with prolong curing period. Glass powder concrete cubes made with (5-20) \% MK and cured for 56 and 90 days, achieved the 28 days target strength of $25 \mathrm{~N} / \mathrm{mm}^{2}$. The optimum replacement level was observed at G10\%M15\% cured for 90 days. The data obtained were subjected to regression analysis and analysis of variance (ANOVA) in the MINITAB 16 statistical software. The model developed to predict compressive strength with curing period and $M K$ as predictors was highly significant at 5\% level, implying there is no significant difference between the predicted and the experimental values. The coefficients of determination, $R^{2}$ of $90.44 \%$ for the model is reasonably high, indicating a good correlation between the response and the predictor variables.
\end{abstract}

Keywords: Analysis of variance, Compressive strength, Glass powder, Metakaolin and Regression. $* * *$

\section{INTRODUCTION}

The continuous increase in the price of Ordinary Portland Cement (OPC) globally is partly attributed to the insufficient production rate when compared to its demand rate in the construction industries [1]. Considerable efforts have been made worldwide to utilize natural waste or byeproduct as supplementary cementatious materials (SCMs) to improve on the properties of concrete and other cement products. This had been achieved through the use of waste such as saw dust ash, palm oil fuel ash, cow dung ash and glass powder to mention just a few.

Glass is a unique inert material that has similar oxide composition to that of Portland cement and could be recycled many times without changing its chemical properties [1]. Glass waste is readily available in most part of the world. There is no clear information about the total amount (quantity) of waste glass generated in the whole world, due to poor documentation in the Middle East and African countries including Nigeria [2]. However, according to the United Nation, the estimation of solid waste in 2004 is about 200 million tones, out of which seven (7\%) is waste from glass which is equivalent to about 14 million tones. Glass waste is causing a serious environmental problem due to its non biodegradable nature in the whole world and Nigeria in particular [2]. Furthermore, the inadequate space for new landfills is a problem facing many countries including some densely populated cities in Nigeria [3]. One of the most attractive solutions to overcome the environmental impact of glass waste is to use it in concrete as a construction material. Recycling glass powder form or as an aggregate in concrete will help to conserve the earth's natural resources, minimizes the landfills spaces, saves energy and money [3]. More so, the need of large quantities of glass waste in the construction industry, low quality requirement of the waste in concrete production and the widespread nature of construction sites all over the globe are additional benefits of using glass waste in concrete production [4].

Several researchers have revealed that the pozzolanic properties of glass powder are noticeable at particle sizes of below $100 \mu \mathrm{m}$ [4]. Studies conducted by [5] also revealed that glass powder of particle size below $100 \mu \mathrm{m}$ not only has a pozzolanic reactivity but also its effect is greater than fly ash at lower cement replacement level. Similarly, studies carried out by [5-7] have suggested that, the optimum replacement level for cement with glass powder in concrete is approximately $10 \%$. Incorporating glass powder in concrete improves compressive strength, resistance to sulphate attack, chloride ion penetration and increases the possibility of alkali-silica destructive reaction [7]. In view of that, additional supplementary cementing materials such as fly ash, rice husk ash or metakaolin whose oxide composition from the literature indicated low percentage of alkalis-silica reaction activators $\left(\mathrm{K}_{2} \mathrm{O}\right.$ and $\left.\mathrm{Na}_{2} \mathrm{O}\right)$ is required to improve the properties of concrete containing glass powder [8].

Metakaolin (MK) is a highly reactive pozzolana produced by burning of kaolin at temperatures $600-900^{\circ} \mathrm{C}$ [9]. Metakaolin has high silica content in the form of noncrystalline or amorphous nature whose reactivity increased 
by its fineness due to its large surface area [9]. Some of the advantages of using metakaolin in concrete as suggested by [10] are superior mechanical properties, reduction in the heat of cement hydration, reduction of shrinkage in concrete, reduction in permeability of concrete, increase resistance against chemical effect and above all decrease in alkali-silica reaction which results in the formation of denser concrete. Several studies had revealed that the use of MK has contributed positively in strength and durability when used in concrete [10]. This study is aimed at accessing the effect of metakaolin on the compressive strength of concrete containing glass powder.

\section{MATERIALS AND METHODS}

Materials: The waste glass or discarded glass bottles were collected from coca-cola depot in Bauchi state Northeast Nigeria. It was sorted out, washed and sun dried before crushing it by a mechanical crusher to smallest possible size, and then sieved using $75 \mu \mathrm{m}$ British Standard sieve size. The kaolin was procured from a supplier at Alkaleri Local Government Area of Bauchi State Northeast Nigeria. After air drying, it was calcined at $700^{\circ} \mathrm{C}$ to produce metakaolin (MK). After cooling the resultant MK was grinded using pestle and mortar and then sieved using $75 \mu \mathrm{m}$ British Standard sieve size. Ashaka brand of Ordinary Portland Cement (OPC) was used for this study, and the properties of the cement conform to BS EN 197 (1992)-part 1 specification. The coarse aggregates used for the study was normal weight dry aggregates from an igneous rock source with a maximum size of $20 \mathrm{~mm}$, the coarse aggregates was procured from Triacta quarry site in Bauchi state Northeast Nigeria. The dry fine aggregates used for the study was obtained from a stream at Bayara town along Bauchi-Dass road, Northeast Nigeria. The aggregates were tested in accordance with BS 882: (1983) specification. The water used for the study was from tap source which is free from impurities and almost fit for drinking.

\subsection{Characterisation of Glass Powder (GP) and}

\section{Metakaolin (MK)}

The physical properties of GP and MK were carried out at the structures laboratory of Department of Civil Engineering, ATBU, Bauchi. The oxide composition test of the representative samples of glass powder and metakaolin were carried out using XRF spectrometer to ascertain the oxide constituents. The tests were conducted at the quality control laboratory of Ashaka Cement Factory Gombe, North Eastern Nigeria. The result of the physical properties as well as the oxide composition of GP, MK and Ashaka cement is presented in table 1 and 2.

\subsection{Production of Concrete using Constituent}

\section{Materials}

Concrete cubes of size $100 \mathrm{~mm}$ x $100 \mathrm{~mm}$ x $100 \mathrm{~mm}$ were produced using the six (6) mix proportion as presented in table 1 . The concrete were cured by complete water immersion for 7, 14, 28, 56 and 90days. The water-cement used was 0.48 by weight of cement and the approximate mix ratio for the constituent materials used was 1:1.5:3. The study was carried out using target mean strength of grade 25 $\mathrm{N} / \mathrm{mm}^{2}$. MK and GP were used as cement replacement in concrete production. The levels of replacement for cement with MK were at $0,5,10,15$ and 20 percent while the GP was kept constant at $10 \%$ cement replacement in line with [11-13] recommendations. A total of ninety (90) samples of concrete cubes were cast, cured and tested. For each curing period, three (3) cubes were produced and the average of the three results was recorded and used.

Table 1: Mix proportions of constituent materials used for MK/GP concrete production

\begin{tabular}{|l|l|l|l|l|l|l|}
\hline \multirow{2}{*}{$\begin{array}{l}\text { MIX } \\
\text { ID }\end{array}$} & \multicolumn{6}{|l|}{ Constituents Materials $\left(\mathrm{Kg} / \mathrm{m}^{3}\right)$} \\
\cline { 2 - 7 } & \begin{tabular}{l} 
Binders \\
\cline { 2 - 7 } \\
\cline { 2 - 7 } $\left.\mathrm{m}^{3}\right)$
\end{tabular} & $\begin{array}{l}\text { MK } \\
(\mathrm{Kg} / \\
\left.\mathrm{m}^{3}\right)\end{array}$ & $\begin{array}{l}\text { Cem } \\
\text { ent } \\
(\mathrm{Kg} / \\
\left.\mathrm{m}^{3}\right)\end{array}$ & $\begin{array}{l}\text { Coar } \\
\text { se } \\
(\mathrm{Kg} / \\
\left.\mathrm{m}^{3}\right)\end{array}$ & $\begin{array}{l}\text { Fine } \\
(\mathrm{Kg} / \\
\left.\mathrm{m}^{3}\right)\end{array}$ & $\begin{array}{l}\text { Water } \\
(\mathrm{Kg} / \\
\left.\mathrm{m}^{3}\right)\end{array}$ \\
\hline $\begin{array}{l}\text { M0G } \\
0\end{array}$ & 0 & 0 & 385 & 1170 & 663 & 185 \\
\hline $\begin{array}{l}\text { M0G } \\
10\end{array}$ & 32 & 0 & 346 & 1170 & 663 & 185 \\
\hline $\begin{array}{l}\text { M5G } \\
10\end{array}$ & 32 & 14 & 329 & 1170 & 663 & 185 \\
\hline $\begin{array}{l}\text { M10 } \\
\text { G10 }\end{array}$ & 32 & 27 & 311 & 1170 & 663 & 185 \\
\hline $\begin{array}{l}\text { M15 } \\
\text { G10 }\end{array}$ & 32 & 41 & 294 & 1170 & 663 & 185 \\
\hline $\begin{array}{l}\text { M20 } \\
\text { G10 }\end{array}$ & 32 & 55 & 277 & 1170 & 663 & 185 \\
\hline
\end{tabular}

\subsection{Slump Test}

Slump test of the freshly prepared concrete was carried out to determine the effect of GP/MK cement replacement on the workability of concrete at the structures laboratory of Department of Civil Engineering, ATBU, Bauchi. The test was conducted in accordance with BS EN 12350: Part 2 (1999) specifications.

\subsection{Compressive Strength Test}

The compressive strength test was carried out on the hardened cured concrete samples. The samples were tested using the ELE motorized compression machine. The test was conducted in accordance with BS EN 12390, Part 4 (2000) specifications. The compressive strength of the concrete cubes was determined using equation (1).

$$
\text { compressive strength }=\frac{\text { Failure Load }(\mathrm{KN})}{\text { Area of Specimen }\left(\mathrm{mm}^{2}\right)} .
$$

\section{RESULTS AND DISCUSSIONS}

\subsection{Physical Properties and Oxide Composition of}

\section{Glass Powder (GP)}

The result of some physical properties of GP is presented in table 2. The loss on ignition (LOI) which is a measure of 
organic and carbonate content and sediment in GP is $3.53 \%$ which is below the maximum of $10 \%$ specified by ASTM C618 (2012). The low LOI in GP indicates its high reactivity when blended in concrete [14]. The specific gravity of GP is 2.61, while that of Ashaka cement is 3.15 . This indicates that GP is lighter than cement and more volume of GP will be required to replace equal weight of cement in concrete. The $\mathrm{pH}$ obtained was 7.8 , this value shows that GP is neither acidic $(\mathrm{pH}<7.0)$ nor alkaline $(\mathrm{pH}>11.0)$ but neutral ( $\mathrm{pH}$ between7-11). This implies that GP can be used in concrete without much concern for durability related problem [14]. The result of oxide composition test conducted on GP reveals the presence of similar oxides to those of cement as shown in table 3, which implies that it can be conviniently used as cement replacement materials. The sum of pozzolanic oxides of Silicon, Iron and Aluminium is $75.43 \%$ exceeds the $70 \%$ minimum specified by ASTM C618 (2012) for raw or calcined pozzolana (class $\mathrm{N})$. The combined alkalis $\left(\mathrm{N}_{2} \mathrm{O}+\right.$ $\mathrm{K}_{2} \mathrm{O}$ ) percentage of $13.41 \%$ is high and thus increases the possibility of the destructive aggregate alkali reaction which causes disintegration of concrete [15]. Another interesting oxide present is sulphur trioxide $\left(\mathrm{SO}_{3}\right)$ which is $0.1 \%$ and is below the maximum of $4 \%$ specified by ASTM C618 (2012) which shows the tendency for improved durability and prevent unsoundness of the paste [15].

\subsection{Oxide Composition and Physical Properties of}

\section{Metakaolin (MK)}

The result of some physical properties of MK is presented in table 2. The loss on ignition (LOI) which is a measure of organic and carbonate content and sediment is $1.76 \%$ which is below the $10 \%$, the maximum specified by ASTM C618 (2012). The low LOI indicates its high reactivity when blended in concrete [16]. The specific gravity obtained was 2.50, while that of Ashaka cement is 3.15. This indicates that $\mathrm{MK}$ is lighter than cement and more volume of MK will be required to replace equal weight of cement in concrete. The $\mathrm{pH}$ of $\mathrm{MK}$ is 9.5 , this value shows that $\mathrm{MK}$ is neither acidic $(\mathrm{pH}<7.0)$ nor alkaline $(\mathrm{pH}>11.0)$ but neutral $(\mathrm{pH}$ between7-11). This implies that MK can also be used in concrete without much concern for durability related problem [16]. The result of oxide composition test conducted on MK reveals the presence of similar oxides to those of cement as shown in table 3 , which implies that it can also be used as cement replacement materials. The sum of oxides of Silicon, Iron and Aluminium is $95.99 \%$ exceeds the $70 \%$ minimum specified by ASTM C618 (2012) for raw or calcined pozzolana (class $\mathrm{N}$ ). The combined alkalis $\left(\mathrm{N}_{2} \mathrm{O}+\mathrm{K}_{2} \mathrm{O}\right)$ percentage of $1.43 \%$ is low and thus reduces the possibility of the destructive aggregate alkali reaction which causes disintegration of concrete [17]. The presence of sulphur trioxide $\left(\mathrm{SO}_{3}\right)$ was also seen in $\mathrm{MK}$ which is $0.02 \%$ and is below $4 \%$ maximum specified by ASTM C618 (2012) which shows the tendency for improved durability and prevent unsoundness of the paste [17].
Table 2: Some Physical Properties of Cement, GP, MK, Fine Aggregate and Coarse Aggregate

\begin{tabular}{|l|l|l|l|l|l|}
\hline Property & $\begin{array}{l}\text { Cemen } \\
\mathrm{t}\end{array}$ & GP & MK & $\begin{array}{l}\text { Fine } \\
\text { Aggregat } \\
\text { e }\end{array}$ & $\begin{array}{l}\text { Coarse } \\
\text { Aggregat } \\
\mathrm{e}\end{array}$ \\
\hline $\begin{array}{l}\text { Specific } \\
\text { Gravity }\end{array}$ & 3.15 & $\begin{array}{l}2.6 \\
1\end{array}$ & $\begin{array}{l}2.5 \\
0\end{array}$ & 2.62 & 2.66 \\
\hline $\begin{array}{l}\text { Bulk } \\
\text { Density } \\
\left(\mathrm{Kg} / \mathrm{m}^{3}\right)\end{array}$ & - & - & - & 1530 & 1415 \\
\hline $\mathrm{pH}$ & - & 7.8 & 9.5 & - & - \\
\hline $\begin{array}{l}\text { Loss on } \\
\text { Ignition }\end{array}$ & 1.0 & 3.5 & 1.7 & - & - \\
\hline $\begin{array}{l}\text { Blaines } \\
\text { Fineness } \\
\left(\mathrm{m}^{2} / \mathrm{Kg}\right)\end{array}$ & 370 & 305 & 367 & - & - \\
\hline $\begin{array}{l}\text { Aggregat } \\
\mathrm{e} \\
\text { Crushing } \\
\text { value (\%) }\end{array}$ & - & - & - & - & 22.33 \\
\hline
\end{tabular}

Table 3: Oxide Composition of Waste Glass Powder (WGP) and Metakaolin (MK)

\begin{tabular}{|l|l|l|l|}
\hline Oxide & $\begin{array}{l}\text { Waste Glass } \\
\text { Powder }(\%)\end{array}$ & $\begin{array}{l}\text { Metakaolin } \\
(\%)\end{array}$ & $\begin{array}{l}\text { Ashaka Cement } \\
(\%)\end{array}$ \\
\hline $\mathrm{S}_{\mathrm{i}} \mathrm{O}_{2}$ & 69.40 & 52.67 & 19.68 \\
\hline $\mathrm{Al}_{2} \mathrm{O}_{3}$ & 3.81 & 41.96 & 6.44 \\
\hline $\mathrm{Fe}_{2} \mathrm{O}_{3}$ & 2.58 & 1.37 & 3.32 \\
\hline $\mathrm{CaO}$ & 11.54 & 1.23 & 60.92 \\
\hline $\mathrm{MgO}$ & 0.67 & 0.26 & 0.97 \\
\hline $\mathrm{SO}_{3}$ & 0.10 & 0.02 & 2.28 \\
\hline $\mathrm{K}_{2} \mathrm{O}$ & 0.43 & 1.34 & 0.85 \\
\hline $\mathrm{Na}_{2} \mathrm{O}$ & 12.98 & 0.09 & 0.12 \\
\hline
\end{tabular}

\subsection{Workability of GP/MK-OPC Blended Concrete}

The results of the slump test carried out on the fresh concrete with varying percentage of metakaolin (MK) as cement replacement are presented in table 4 while figure 1 shows the plot of slump versus MK in percentage. The results also show that the slump decreases with increase in the amount of MK used, which indicates that more water is required to maintain the same consistency as MK content increases. For instance at 5\%,10\%,15\% and $20 \% \mathrm{MK}$ content, the slump decreases by $19.05 \%, 33.33 \%, 42.86 \%$ and $52.38 \%$ respectively. This implies that MK absorbs more water than ordinary Portland cement in concrete. All the slump values obtained falls within the limit for class S1 (10 mm-40 mm) specified by BS-EN 206-part 1: (2000) as true type of slump which is suitable for most concrete works.

Table 4: Slump test result of MK/GP-OPC blended concrete

\begin{tabular}{|l|l|}
\hline Mix-ID & Slump (mm) \\
\hline M0G0 & 26 \\
\hline M0G10 & 21 \\
\hline M5G10 & 17 \\
\hline M10G10 & 14 \\
\hline M15G10 & 12 \\
\hline M20G10 & 10 \\
\hline
\end{tabular}




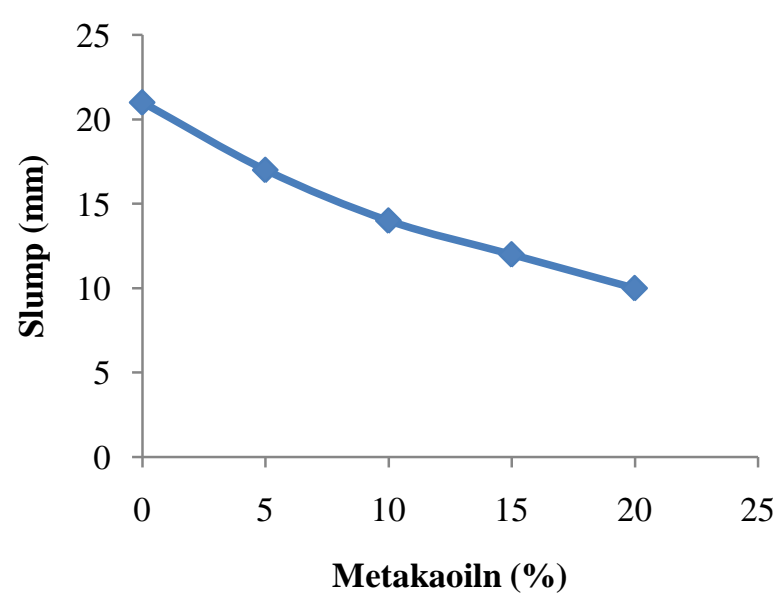

Fig 1: Plot of slump versus metakaolin content

\subsection{Compressive Strength Test Result}

The compressive strength test result is presented in table 5, while figure 2 shows the plot of compressive strength of OPC-GP/MK concrete versus percentage of MK used to replace cement. It can be seen from that figure, generally the compressive strength decreases as the percentage of MK increases. For instance at G10M0 cement replacement level, there was a strength decreases of $11.67 \%, 7.37 \%, 6.46 \%$, $2.25 \%$ and $3.18 \%$ when compared to the compressive strength of control specimen(G0M0) at 7, 14, 28, 56 and 90 days of curing periods respectively. Similarly, G10M5 exhibited strength decrease of $10.86 \%, 7.70 \%, 9.40 \%$, $5.75 \%$ and $4.02 \%$ at $7,14,28,56$ and 90 days of curing periods respectively. All the remaining cement replacement levels, exhibited similar pattern of strength loss when compared to the strength of the control sample. From all the results presented, it can be observed that higher MK additions results in greater reduction of Compressive strength. This behavior may be attributed to two reasons. First, the replacement of cement with $\mathrm{MK}$ in concrete, results in the reduction of tri-calcium silicates $\left(\mathrm{C}_{3} \mathrm{~S}\right)$ which is a main strength contributing compound [18]. Secondly, the fineness of $\mathrm{MK}$ is lesser than that of OPC and consequently cannot hydrate as quickly as cement (within the first 28days) to give the desired strength compared to plain OPC concrete [18].

Table 5: Compressive Strength Test Result for GP/MKOPC Concrete

\begin{tabular}{|l|l|l|l|l|l|}
\hline Mix ID & \multicolumn{5}{|l|}{ Compressive strength $\left(\mathrm{N} / \mathrm{mm}^{2}\right)$} \\
\hline & 7 days & $\begin{array}{l}14 \\
\text { days }\end{array}$ & $\begin{array}{l}28 \\
\text { days }\end{array}$ & $\begin{array}{l}56 \\
\text { days }\end{array}$ & $\begin{array}{l}90 \\
\text { days }\end{array}$ \\
\hline G0M0 & 18.24 & 26.32 & 32.05 & 32.85 & 33.95 \\
\hline G10M0 & 16.11 & 24.38 & 29.98 & 31.33 & 32.87 \\
\hline G10M5 & 14.36 & 22.51 & 27.17 & 29.53 & 31.55 \\
\hline G10M10 & 13.16 & 20.76 & 25.66 & 28.06 & 29.35 \\
\hline G10M15 & 12.18 & 19.43 & 25.08 & 27.88 & 28.82 \\
\hline G10M20 & 11.09 & 17.28 & 22.44 & 25.13 & 27.13 \\
\hline
\end{tabular}

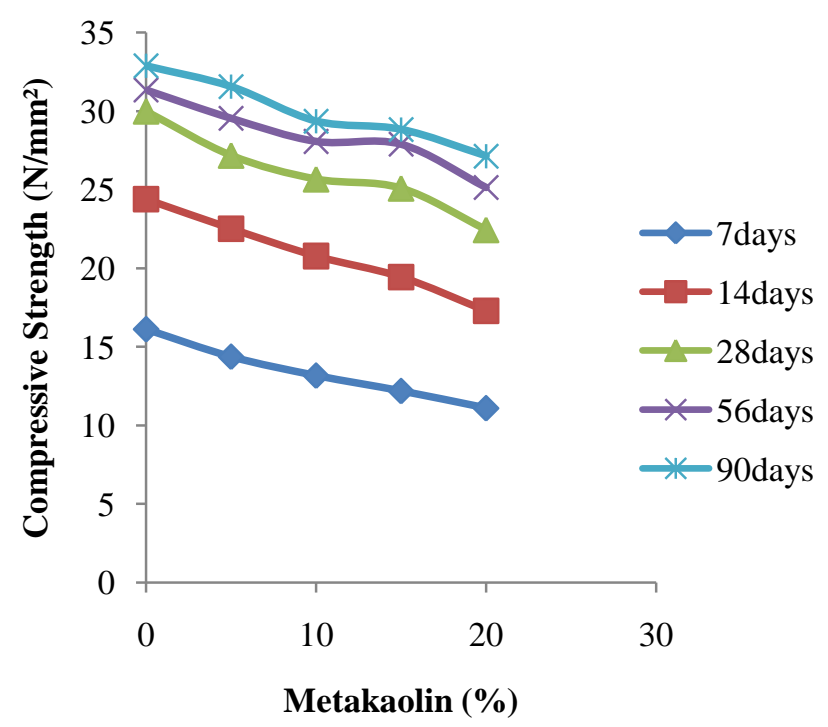

Fig 2: Plot of compressive strength versus metakaolin content

Figure 3 shows the plot of compressive strength of GP/MKOPC concrete versus its curing periods. It can be observed that the compressive strength of the concrete containing MK increases as the curing age is prolonged irrespective of the replacement levels. According to the experimental findings, G10M0 at 7 days curing period, exhibited $44.29 \%, 21.77$ $\%, 2.50 \%$ and $5.78 \%$ increase in strength compared to the control concrete at the end of 14, 28, 56 and 90 days respectively. Similarly, G10M5 exhibited $10.86 \%, 7.70 \%$, $9.40 \%$ and $4.02 \%$ increase in strength compared with the corresponding strength of the plain concrete at the end of 7 , $14,28,56$ and 90 days of curing. All the remaining replacement levels, showed a similar pattern of strength increase. This could be due to $\mathrm{MK}$, which retards the hydration of OPC at early ages and consequently decrease the rate of strength development in concrete. It can be seen from the values presented above that the percentage increase in strength for all MK content used increases up to 28days curing period. However, the percentage increase reduces significantly after 56 and 90 days of curing. This shows that there is a significant strength gain with prolong curing. This is one of the properties of pozzolana which gains strength with time [19]. The possible explanation to this behavior also is that at early ages (28days and below), the MK act as a filler in the concrete with no significant contribution to strength, but at latter ages(beyond 28days) MK react with Calcium Hydroxide released in pozzolanic reaction to produce the strength forming calcium silicate hydrates $(\mathrm{C}-\mathrm{S}$ $\mathrm{H})$. The C-S-H formed is a stable compound and is responsible for the significant latter strength gain [19]. The optimum replacement level was observed at G10M15 because it gives better increase in strength than the remaining replacement levels. The increase in strength generally may be attributed to the cementatious products formed as a result of hydration of cement and those formed when lime react with pozzolana in concrete[20]. 


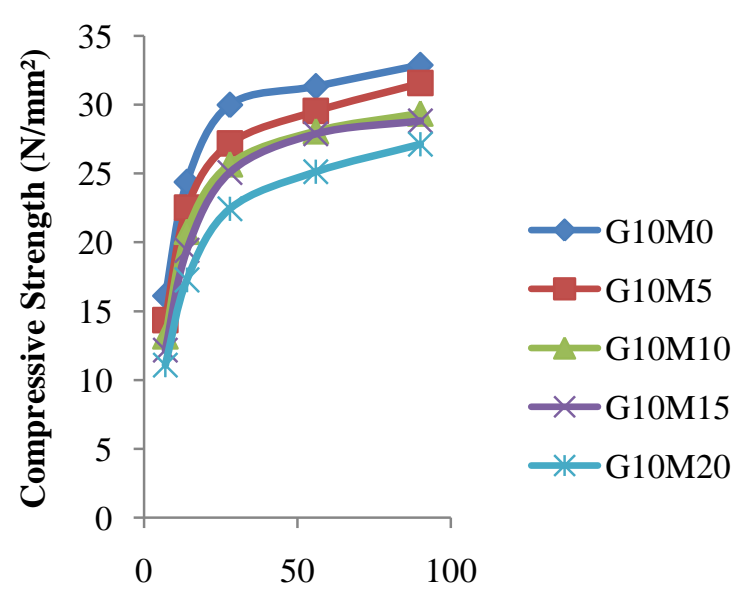

Curing Period (days)

Fig 3: Plot of compressive strength versus age of curing

\subsection{Statistical Analysis of the Compressive Strength}

\section{Results}

Statistical analysis of the data presented in table 5 resulted in table 6, which shows the result of regression analysis on compressive strength results. The regression equation is given by equation (2):

$$
\begin{gathered}
c_{s}=15.9398+0.549235 x_{1}-0.370853 x_{2}+ \\
0.000570601 x_{1} x_{2}-0.00403586 x_{1}^{2}
\end{gathered}
$$

Where $x_{1}$ and $x_{2}$ (predictor variables) are curing period and metakaolin content respectively, while $C_{S}$ is the compressive strength (Response variable) which is the response in the model equation. The $\mathrm{P}$-values is a measure of the likelihood that the true coefficient is zero. From the pvalues of the terms in the model, it can be seen that the constant, $x_{1}, x_{2}, x_{1}{ }^{2}$ are highly significant at $(\mathrm{P}<0.05)$ and thus are useful predictors in the regression model developed but, $\mathrm{x}_{1} \mathrm{x}_{2}$ (interaction between Metakaolin and curing period) is not sinificant. Therefore, it can be concluded that all predictor variables except $\mathrm{x}_{1} \mathrm{x}_{2}$ significantly influence the response (Compressive strength in this case).The coefficient of variation of the selected model obtained was $90.44 \%$ ( $\mathrm{R}^{2}=90.44 \%$ ). This implies that $90.44 \%$ of variation in the compressive strength is explained by the regression model with curing period and MK content as predictor variables. The standard deviation of the model equation, $\mathrm{S}=2.22639$. The smaller the $\mathrm{S}$ value, the better the model equation, which shows a perfect correlation between predictors and the response, implying that the generated model is highly significant [21].

The compressive strength results were further subjected to a one way analysis of variance (ANOVA).The computation is presented Table 6. Although, the concrete cubes containing GP/MK have lower compressive strength compared to the control samples, there was no statistically significant difference between the compressive strength of control samples and those of concrete containing GP/MK $(\rho>0.05)$ at $5 \%$ level of significance.

\begin{tabular}{|c|c|c|c|c|c|}
\hline Predictor & Coeff & $\begin{array}{l}\text { SE } \\
\text { Coeff }\end{array}$ & $\mathrm{T}$ & $\mathrm{P}$ & Remarks \\
\hline Constant & $\begin{array}{l}15.939 \\
8\end{array}$ & $\begin{array}{l}1.2677 \\
7\end{array}$ & $\begin{array}{l}12.573 \\
1\end{array}$ & 0.000 & $\begin{array}{l}\text { Significa } \\
\mathrm{nt}\end{array}$ \\
\hline $\mathrm{x}_{1}$ & 0.5492 & $\begin{array}{l}0.0613 \\
4\end{array}$ & 8.9539 & 0.000 & $\begin{array}{l}\text { Significa } \\
\mathrm{nt}\end{array}$ \\
\hline $\mathrm{x}_{2}$ & $\begin{array}{l}- \\
0.3709\end{array}$ & $\begin{array}{l}0.0884 \\
7\end{array}$ & -4.1916 & 0.000 & $\begin{array}{l}\text { Significa } \\
\mathrm{nt}\end{array}$ \\
\hline $\mathrm{x}_{1} \mathrm{x}_{2}$ & 0.0006 & $\begin{array}{l}0.0017 \\
9\end{array}$ & 0.3194 & 0.752 & $\begin{array}{l}\text { Not } \\
\text { significa } \\
\text { nt }\end{array}$ \\
\hline $\mathrm{x}_{1}^{2}$ & $\begin{array}{l}- \\
0.0040\end{array}$ & 0.0060 & $\begin{array}{l}- \\
6.7394\end{array}$ & 0.000 & $\begin{array}{l}\text { Significa } \\
\text { nt }\end{array}$ \\
\hline \multicolumn{6}{|c|}{ Basic ANOVA } \\
\hline Source & $\mathrm{DF}$ & $\mathrm{SS}$ & MS & $\mathrm{F}$ & $\mathrm{P}$ \\
\hline $\begin{array}{l}\text { Regressi } \\
\text { on }\end{array}$ & 4 & $\begin{array}{l}1172.1 \\
2\end{array}$ & $\begin{array}{l}293.03 \\
0\end{array}$ & $\begin{array}{l}59.116 \\
6\end{array}$ & 0.000000 \\
\hline $\mathrm{x}_{1}$ & 1 & 743.94 & $\begin{array}{l}397.39 \\
6\end{array}$ & $\begin{array}{l}80.171 \\
6\end{array}$ & 0.000000 \\
\hline $\mathrm{x}_{2}$ & 1 & 202.54 & 87.091 & $\begin{array}{l}17.569 \\
9\end{array}$ & 0.000302 \\
\hline $\mathrm{x}_{1} \mathrm{X}_{2}$ & 1 & 225.14 & 0.506 & 0.1020 & 0.752061 \\
\hline $\mathrm{x}_{1}^{2}$ & 1 & 123.92 & $\begin{array}{l}225.13 \\
6\end{array}$ & $\begin{array}{l}45.419 \\
5\end{array}$ & 0.000000 \\
\hline Error & 25 & 115.89 & 4.957 & - & - \\
\hline $\begin{array}{l}\text { Lack of } \\
\text { fit }\end{array}$ & 20 & 8.03 & 5.794 & 3.6075 & 0.79809 \\
\hline $\begin{array}{l}\text { Pure } \\
\text { error }\end{array}$ & 5 & - & 1.606 & - & - \\
\hline Total & 29 & - & - & - & - \\
\hline
\end{tabular}

Table 6: Regression analysis of compressive strength

\section{CONCLUSION}

Based on the results obtained, the following conclusions were drawn

i. Compressive strength generally decreases with increase in metakaolin (MK) content and increase with increase in curing period.

ii. The optimum replacement level of the blended concrete was obtained at G10\% M15\% and cured for 90 days. The optimum recorded highest strength increase of compressive strength over the control sample when compared to other cement replacement levels.

iii. The workability was reduced by incorporating MK in concrete, hence more water is required to maintain uniform slump.

iv. The regression model for compressive strength is given by $c_{s}=15.9398+0.549235 x_{1}-0.370853 x_{2}+$ $0.000570601 x_{1} x_{2}-0.00403586 x_{1}^{2} \quad, \quad \mathrm{R}^{2}=90.44 \%$ where $\mathrm{x}_{1}$ and $\mathrm{x}_{2}$ are curing period and metakaolin content respectively.

v. The statistical model developed provides good prediction for the compressive strength and there is no statistical significant difference between the experimental and predicted strength values at $5 \%$ level of significance.

vi. Curing period and metakaolin content are useful predictors of the regression model for compressive strength. 


\section{REFERENCES}

[1]. Nwofor, T.C., and Sule, S. (2012). Stability of Groundnut Shell Ash (CSA)/Ordinary Portland Cement (OPC) Concrete in Nigeria. Pelajia Research Library, 3(4): 2283-2287.

[2]. Jani, Y., and Hogland, W. (2014). Waste Glass in the Production of Cement and Concrete. A Review: Journal of Environmental Chemical Engineering, 2(14): 1767-1775.

[3]. Madandoust, R., and Ghavidel, R. (2013). Mechanical Properties of Concrete Containing Waste Glass Powder and Rice Husk Ash. Journal of Biosystem Engineering, 6(11): 113-119.

[4]. Schwarz, N., Cam, H. and Neithalath, N. (2008). Influence of Fine Glass Powder on the Durability Characteristics of Concrete and its Comparison to Fly Ash. Cement and Concrete Composites, Vol. 30: 486-496.

[5]. Cheng, C. H. (2002). TFT-LCD Discussion on the Status of Waste Disposal in Manufacturing Industry. Centre for Environmental Safety Industry Technology Research Institute, 8(15): 22-29.

[6]. Shi, C., Wu, Y., Riefler, C. and Wang, H. (2005). Characteristics and Pozzolanic reactivity of Glass Powders. Cement and Concrete Research, 5(3): 987-912.

[7]. Matos, A.M and Sausa Countinho, J. (2012). Durability of Mortar Using Waste Glas Powder as Cement Replacement. Construction and Building Materials, 3(5): 205-215.

[8]. Khimiri, A., Chabouni, M. and Samet, B. (2013). Chemical Behavior of Ground Waste Glass when used as Partial Replacement of Cement in Mortars. Construction and Building Materials, 4(4): 74-80.

[9]. Rashad A. M. (2013). Metakaolin as Cementitious Material: History, Scours, Production and Composition: A Compressive Overview. Construction and Building Materials, 4(1): 308-318.

[10]. Poon C.S; Lam, L., Kou, S.C., Wong, Y.L; and Wong, R. (2001). Rate of Pozzolanic Reaction of Metakaolin in High Performance Cement Pastes. Cement and Concrete Research, 39(1): 1301-1306.

[11]. Tan, K. H., and Du, H. (2013). Use of Waste Glass as Sand in Mortar Fresh, Mechanical and Durability Properties. Cement and Concrete Composites, 7(35): 109-117.

[12]. Topcu, I. B., and Canbaz, M. (2004). Properties of Waste Glass. Cement and Concrete Research, 2(34): 267274.

[13]. Shi-Chaijun, A., and Keren, Z. (2007). A Review on the Use of Waste Glass in the Production of Cement and Concrete. Resources, Conservation and Recycling, 12(52): 234-247.

[14]. Falade, F., Efe, I., and Fapohunda, L. (2012). Potential of Pulverized Bone as a Pozzolanic Material. International Journal of Scientific and Engineering Research, 3(7): 1-6.

[15]. Yilmaz, K. (2012). Study on the Effect of Fly Ash and Silica Fume Substituted Cement Paste and Mortars. Scientific Research and Essays, 5(19): 990-998.

[16]. Morsy, M.S, Shebi. S.S and Rashad, A. M. (2010). Effect of Fire on Micro structure and Mechanical Properties of Blended Cement Paste Containing Metakaolin and Silica Fumes, Sillic Ind. 5(6): 173-185.
[17]. Siddique, R., and Klaus, J. (2009). Influence of Metakaolin on the Properties of Mortar and Concrete. International Journals of Engineering Research, 15(43): 392-400.

[18]. Ramezanianpour, A. A., and Jovein, H. (2011). Metakaolin as Supplementary Cementitious Materials on Strength and Durability of Concretes. Construction and Building Materials, 30(28): 470-479.

[19]. Emiroglu, M., and Subasi, A. (2015). Effect of Metakaolin Substitution on Physical, Mechanical and Hydration Process of White Portland Cement. Construction and Building Materials, 5(15): 257-268.

[20]. Neville, A. M and Brooks, J. J. (1997). Concrete Technology $\left(4^{\text {th }}\right.$ edition $)$ Longman Publishers Limited, England, Pp 8-20, 34-37 and 420-430.

[21]. John Pan (2013). Minitab Tutorial and Design of Experiment. International Journal of Scientific and Engineering Research, 2(6): 1-32. 